\title{
NEW PROVINCIAL RECORDS AND AN UPDATED LIST OF SNAKES (Squamata: Serpentes) FROM XUAN LIEN NATURE RESERVE, THANH HOA PROVINCE, VIETNAM
}

\author{
Nguyen Van Tan, Pham The Cuong, Nguyen Quang Truong* \\ Institute of Ecology and Biological Resources, VAST
}

\begin{abstract}
We report six new records of snakes from Thanh Hoa province based on newly collected specimens from Xuan Lien Nature Reserve, comprising three species of Colubridae (Lycodon futsingensis, L. meridionalis and Oreocryptophis porphyraceus), two species of Natricidae (Hebius boulengeri and Parahelicops annamensis), and one species of Elapidae (Bungarus slowinskii). In addition, an updated list of 38 snake species from Xuan Lien Nature Reserve is also provided. The snake fauna of Xuan Lien Nature Reserve contains a number of species of conservation concern including six species listed in the Governmental Decree No. 32/2006/ND-CP (2006), eight species listed in the Vietnam Red Data Book (2007), and four species listed in the IUCN Red List (2016).
\end{abstract}

Keywords: Distribution, snakes, species list, Xuan Lien Nature Reserve.

Citation: Nguyen Van Tan, Pham The Cuong, Nguyen Quang Truong, 2016. New provincial records and an updated list of snakes (Squamata: Serpentes) from Xuan Lien Nature Reserve, Thanh Hoa province, Vietnam. Tap chi Sinh hoc, 38(3): 324-332. DOI: 10.15625/0866-7160/v38n3.8448.

*Corresponding author: nqt2@yahoo.com.

\section{INTRODUCTION}

The Xuan Lien Nature Reserve is located in Thuong Xuan district, Thanh Hoa province, Vietnam, covering an area of 27,668 ha of montane evergreen forest [18]. Although this protected area was established in 2000, the herpetofauna of Xuan Lien Nature Reserve is still poorly studied. Le et al. (1999) [10] provided the first list of 16 snake species from this reserve. Le \& Pham (2009) [9] reported a total of 28 species of snakes from Xuan Lien Nature Reserve. Pham et al. (2012) [17] subsequently documented only 22 species of snakes from this nature reserve, including eight new provincial records for Thanh Hoa province. In this paper, we report six additional species for the list of snakes from Thanh Hoa province based on the new reptile collection from Xuan Lien Nature Reserve.

\section{MATERIAL AND METHODS}

Field surveys were conducted in the Xuan Lien Nature Reserve by C. T. Pham, C. V. Hoang, T. T. Nguyen, T. T. Chu from 1 to 10 November 2011 , from 15 to 25 April, from 20 to 30 August 2012 and from 20 to 28 April
2013. Surveys sites were situated at elevations from $200 \mathrm{~m}$ to $1000 \mathrm{~m}$ above sea level (asl.). Specimens were collected at night time between 19:00 and 23:30 by hand or using a snakehook. Specimens were anaesthetized with ethyl acetate, fixed in 90\% ethanol for 10-12 hours, and subsequently transferred into $70 \%$ ethanol for permanent storage. Specimens were deposited in the collection of the Institute of Ecology and Biological Resources (IEBR), Hanoi, Vietnam.

Taxonomic identification of the specimens were made mainly based on the following literature: Gressit (1937) [4], Smith (1943) [20], Schulz (1996) [19], Orlov et al. (2004) [16], Kuch et al. (2005) [8], Stuart (2006) [21], Vogel et al. (2009) [25], Kharin et al. 2011 [7], Hecth et al. (2013) [5], Luu et al. (2013a, b) [11,12], Nguyen et al. (2014) [14], Ziegler et al. 2014 [26], David et al. (2013, 2015b) [1, 3]. For common names, we followed Nguyen et al. (2009) [13] and Uetz \& Hošek (2016) [24].

Abbreviations used for morphometry are as follows: SVL (snout-vent length): from tip of snout to anterior margin of cloaca; TaL (Tail 
length): from posterior margin of cloaca to tip of tail. Bilateral scale counts were given as left/right.

\section{RESULTS AND DISCUSSION}

\section{Taxonomic accounts}

\section{Family Colubridae}

\section{Lycodon futsingensis (Pope, 1928)}

Futsing Wolf Snake/Rắn khuyết fut-sing (Fig. 1a)

Specimen examined $(n=2)$. One adult male, IEBR 3900 (Field no. XL-TH.2011.51), collected on 5 November 2011 near Vin Forest Ranger Station $\left(19^{\circ} 58.777^{\prime} \mathrm{N}, 104^{\circ} 59.084^{\prime} \mathrm{E}\right.$, at an elevation of $873 \mathrm{~m}$ asl.); one adult male IEBR 3901 (Filed no. XL-TH.2012.2) collected on 15 April 2012 near the Hon Can Forest Ranger Station $\left(19^{\circ} 51.645^{\prime} \mathrm{N}, \mathrm{E} 105^{\circ} 14.558^{\prime} \mathrm{E}\right.$, at an elevation of $170 \mathrm{~m}$ asl.).

Morphological characters. IEBR 3900 (SVL $722.3 \mathrm{~mm}$, TaL $128.5 \mathrm{~mm}$ ), IEBR 3901 (SVL $577 \mathrm{~mm}$, TaL $162.8 \mathrm{~mm}$ ). Body elongated; head distinct from neck; eye moderate; pupil vertically oval; rostral broader than high, partly visible from above; internasals as broad as long, not in contact with loreal; prefrontal as long as frontal; frontal hexagonal; parietals large, longer than wide; nasal divided; loreal $1 / 1$, small, not touching the eye; preocular $1 / 1$; subocular absent; postoculars 2/2; anterior temporals $2 / 2$; posterior temporals $2 / 2$ or $3 / 3$; supralabials $8 / 8$, third to fifth entering orbit; infralabials $10 / 10$, first to fifth bordering chin shields; dorsal scale rows 17-17-15, all smooth; ventrals 195-199; cloacal entire; subcaudals 4675, all paired. Hemipenis short, unforked, reaching the $5^{\text {th }}$ or $6^{\text {th }} \mathrm{SC}$.

Coloration in life. Above pale brownish grey with 23-25 brownish rings on body and 8-10 rings on the tail. The rings wider at base, the first one starting at ventral scale 16 or 17 , in width of 5-6 ventrals at its base and of 2 or 3 dorsal sacles on dorsum. Belly cream, with dark marbling, dark grey posteriorly (determination after Vogel et al. 2009 [25], Hecht et al. 2013 [5], Luu et al. 2013a [11] and Nguyen et al. 2014 [14]).

Ecological notes. The specimens were found between 19:00 and 22:00 in two small streams. The surrounding habitat was mixed secondary forest of small hardwoods, shrubs and bamboos.

Distribution. In Vietnam, this species is known from Lao Cai, Bac Kan, Bac Giang, Vinh Phuc, Ha Tinh and Quang Binh provinces [25]. Elsewhere, this species is recorded from Laos [11].

\section{Lycodon meridionalis (Bourret, 1935)}

Southern Big-tooth Snake/Rắn lệch đầu kinh tuyến (Fig. 1b)

Specimen examined $(\mathrm{n}=1)$. One adult female, IEBR 3902 (Field no. XL-TH.2013.1), collected on 5 April 2013 near Vin Forest Ranger Station $\left(19^{\circ} 59.498^{\prime} \mathrm{N}, 104^{\circ} 57.907^{\prime} \mathrm{E}\right.$, at an elevation of $886 \mathrm{~m}$ asl.).

Morphological characters. SVL $1102.3 \mathrm{~mm}$, TaL 234 mm. Body elongated; head distinct from neck; eye large; pupil vertically oval; rostral as broad as high, partly visible from above; internasals as broad as long, not in contact with loreal; prefrontal shorter than frontal; frontal hexagonal; parietals longer than wide; nasal divided; loreal 1/1, small, not touching the eye; preocular $1 / 1$; subocular absent; postoculars $2 / 2$; anterior temporals $2 / 2$; posterior temporals $2 / 3$; supralabials $8 / 8$, third to fifth entering orbit; infralabials $10 / 10$, first to fifth bordering chin shields; dorsal scale rows 17-17-15, strongly keeled except 5 outermost rows smooth, outer dorsal scales enlarged; ventrals 251; cloacal entire; subcaudals 75, paired.

Coloration in life. Dorsum black with 110 yellow narrow cross-bars on body and 26 on tail, bifurcate on the sides, enclosing dark spots; head black with symmetrical light markings, the most conspicuous being one running from the eye to the margin of the snout and another stretching from the hind margin of the parietals. Belly light yellow (determination after Orlov et al. 2004 [16], Hecth et al. 2013 [5] and Ziegler et al. 2014 [26]).

Ecological notes. The specimen was found at 21:00 in a small stream. The surrounding habitat was mixed secondary forest composed of small to medium hardwoods and shrubs.

Distribution. In Vietnam, this species is known from Lao Cai and Ha Giang provinces 
southwards to Ninh Binh province [13]. Elsewhere, the species is recorded from China and Laos [13].

Oreocryptophis porphyraceus (Cantor, 1839)Black-banded Trinket Snake/Rắn sọc đốm đỏ (Fig. 1c)

Specimen examined $(n=1)$. One juvenile, IEBR 3903 (Field no. XL-TH.2012.91), collected in 21 April 2012 near Hon Can Ranger Station $\left(19^{\circ} 57.604^{\prime} \mathrm{N}, 105^{\circ} 14.371^{\prime} \mathrm{E}\right.$, at an elevation of $210 \mathrm{~m}$ asl.).

Morphological characters. SVL $238.3 \mathrm{~mm}$, TaL 54.46 mm. Body elongated; head distinct from neck; eye large; rostral as broad as high, visible from above; internasals as broad as long, not in contact with loreal; prefrontal less than length of frontal; frontal hexagonal; parietals large, longer than wide; nasal divided; loreal $1 / 1$, small, not touching the eye; preocular $1 / 1$, large; subocular absent; postoculars 2/2; anterior temporals $1 / 1$; posterior temporals $2 / 2$; supralabials $8 / 8$, four and fifth entering orbit, seventh largest; infralabials $10 / 10$, first to fifth chin shields bordering; dorsal scale rows 19-1917, all smooth; ventrals 205; cloacal paired; subcaudals 75, paired.

Coloration in preservative. Ground color reddish brown; body and tail with dark bands, bordered in black; two narrow black stripes extending from immediately behind eyes along entire length of the body; dorsal surface of head marked with a black line (determination after Smith 1943 [20], Schulz 1996 [19] and Ziegler et al. 2014 [26]).

Ecological notes. The specimen was found at 21:30 on forest path. The surrounding habitat was mixed secondary forest of small hardwoods, shrubs and bamboos.

Distribution. This species is known from northern Vietnam southwards to Quang Binh Province [13]. Elsewhere, the species is recorded from India, Nepal, China, Taiwan, Myanmar, Laos, Thailand, Cambodia, Malaysia, and Indonesia [13].

\section{Family Natricidae}

Hebius boulengeri (Gressitt, 1937)
Tai-yong Keelback/Rắn sãi bâu-len-giơ (Fig. 1d)

Specimen examined $(n=1)$. One subadult male, IEBR.3904 (Field no. XL-TH.2012.1), collected by CTP et al. on 2 Arpil 2012 near the Hon Can Forest Ranger Station (19 $51.645^{\prime} \mathrm{N}$, $104^{\circ} 14.558^{\prime} \mathrm{E}$, at an elevation of $170 \mathrm{~m}$ asl.).

Morphological characters. SVL $337.1 \mathrm{~mm}$, TaL 106 mm. Body cylindrical, elongated; head flattened, distinct from neck; eye moderate; pupil round; maxillary teeth $25 / 25$; rostral wider than high, partly visible from above; internasals subrectangular, truncated, not in contact with loreal, as long as prefrontal; prefrontal shorter than frontal; frontal hexagonal; parietals longer than wide; nasal undivided; loreal $1 / 1$, small, not touching the eye; preocular $1 / 1$; subocular absent; postoculars $3 / 3$; anterior temporal $1 / 1$; posterior temporal $1 / 1$; supralabials $9 / 9$, fourth to sixth entering orbit, seventh largest; infralabials $11 / 11$, first to fifth bordering chin shields; dorsal scale rows 19-19-17, strongly keeled except outer row smooth; ventrals 141; cloacal entire; subcaudals 53, paired. Hemipenis short, reaching the $4^{\text {th }} \mathrm{SC}$.

Coloration in life. Dorsal surface of body dark grey, distinctly darker on the five upper dorsal scale rows than on the sides; dorsolateral stripe extends from the neck to the base of the tail. Posterior supralabials dark brown, each with a median, horizontal and longate, thin cream blotch or streak, usually united as a narrow stripe, extending on the neck as a continuous stripe. The venter uniformly cream (determination after Gressit 1937 [4], David et al. 2013 [1]).

Ecological notes. The specimen was found at 20:45 in a small stream. The surrounding habitat was mixed secondary forest of small hardwoods, shrub and arrowroot.

Distribution. In Vietnam, this species is known from Lao Cai and Ha Giang provinces southwards to Dak Lak and Lam Dong provinces [1]. Elsewhere, the species is recorded from China, Laos, Cambodia, and Thailand [1].

\section{Parahelicops annamensis Bourret, 1934}

Annam Keelback/Rắn bình mũi trung bộ (Fig. 1e)

Specimen examined $(n=1)$ One 
adult female, IEBR 3905 (Field no. XLTH.2013.24), collected on 21 Arpil 2013 near the Vin Forest Ranger Station $\left(19^{\circ} 59.111^{\prime} \mathrm{N}\right.$, $104^{\circ} 58.215^{\prime} \mathrm{E}$, at an elevation of $850 \mathrm{~m}$ asl.).
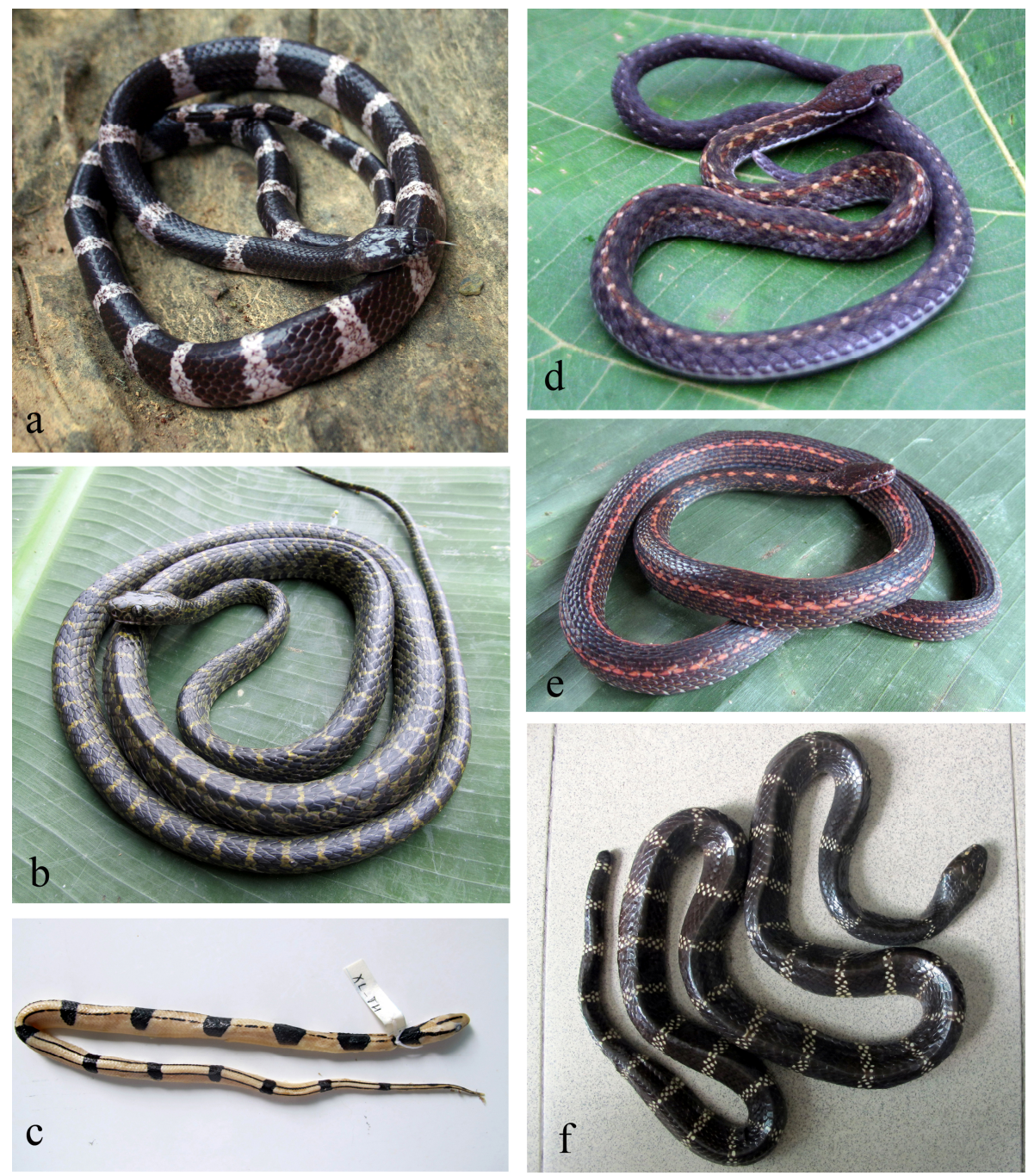

Figure 1. New provincial records of snakes from Xuan Lien Nature Reserve, Thanh Hoa province: (a) Lycodon futsingensis (IEBR 3900, adult male); (b) Lycodon meridionalis (IEBR 3902, adult female); (c) Oreocryptophis porphyraceus (IEBR 3903, juvenile); (d) Hebius boulengeri (IEBR 3904, subadult male); (e) Parahelicops annamensis (IEBR 3905, adult female); and (f) Bungarus slowinskii (IEBR 3906, adult female).

Morphological characters. SVL $402.7 \mathrm{~mm}$, TaL $169 \mathrm{~mm}$. Body moderately robust; head moderately distinct from neck; eye small; pupil round; rostral hexagonal, wider than high, barely visible from above; internasals narrowed anteriorly; prefrontal broader than long; frontal hexagonal; parietals longer than wide; nasal undivided; loreal 1/1, not touching the eye; preocular 1/1; subocular absent; postoculars $1 / 3$; anterior temporal $1 / 1$, posterior temporal $1 / 1$; supralabials $9 / 9$, fourth to sixth entering orbit, seventh largest; infralabials 10/10, first to fifth bordering chin shields; dorsal scale rows 19-1717 , strongly keeled; ventrals 165 ; cloacal paired, subcaudals 106, paired.

Coloration in life. Dorsum dark purplish 
brown; the dorsolateral blotches bright orange; the postocular streak orange on the neck. Belly pale reddish pink (determination after Stuart 2006 [21], Luu et al. 2013b [12] and David et al. 2015b [3])

Ecological notes. The specimen was found at 22:00 in a small stream. The surrounding habitat was mixed secondary forest of small to medium hardwoods and shrubs.

Distribution. In Vietnam, this species is known from Ha Tinh, Quang Binh, Quang Tri, Thua Thien Hue, Da Nang, and Kon Tum provinces [3]. Elsewhere, this species is recorded from Laos [3].

Remarks. Parahelicops annamensis is morphologically similar to Pararhabdophis chapaensis but it differs from $P$. chapaensis by having venter pale, more subcaudals (116-146 vs. 90-114 in P. chapaensis) [3].

\section{Family Elapidae}

Bungarus slowinskii Kuch, Kizirian, Nguyen, Lawson, Donnelly \& Mebs, 2005

Red River Krait/ Rắn cạp nia sông hồng (Fig. 1f)

Specimen examined $(n=1)$. One adult female, IEBR 3906 (Field no. XL-TH.2011.1), collected on 2 November 2011 near Vin Forest Ranger Station $\left(19^{\circ} 58.975^{\prime} \mathrm{N}, 104^{\circ} 58.413^{\prime} \mathrm{E}\right.$, at an elevation $730 \mathrm{~m}$ asl.).

Morphological characters. SVL $1300 \mathrm{~mm}$, TaL $157.81 \mathrm{~mm}$. Body elongated; head distinct from neck; eye small; rostral broader than high, visible from above; internasals narrow; prefront shorther than frontal; frontal scute hexagonal; parietals as long as wide; nasal divided; loreal absent; preocular 1/1; subocular absent; postoculars 2/2; anterior temporals $1 / 1$; posterior temporals $2 / 2$; supralabials $7 / 7$, third and fourth entering orbit, sixth largest; infralabials $7 / 7$, first to third bordering chin shields; mental small; dorsal scale rows 15-1515 , all smooth, vertebral scales and outer dorsal scale enlarged; ventrals 229; cloacal entire; subcaudals 40, paired.

Coloration in preservative. Body and tail with pattern of dark and light rings with 35 narrow white cross bands on body and 5 narrow white cross bands on tail, tip of tail black (determination after Kuch et al. 2005 [8] and Kharin et al. 2011 [7])

Ecological notes. The specimen was found at 22:00 in a rocky stream. The surrounding habitat was mixed secondary forest of small to medium hardwoods and shrubs.

Distribution. In Vietnam, this species is known from Lao Cai, Yen Bai, Quang Tri, Thua Thien Hue, and Quang Nam provinces [7]. Elsewhere, this species is recorded from Laos [7].

\section{Discussion}

Our new records bring the total number of snake species in Xuan Lien Nature Reserve to 38. Le et al. 1999 [10] and Le \& Pham (2009) [9] reported the occurrence of Hebius parallelum in the Xuan Lien Nature Reserve. However, David et al. (2015b) [2] stated that the distribution of $H$. parallelum is restricted to India and Nepal. Therefore, the record of $H$. parallelum from Xuan Lien might be a misidentification of $H$. boulengeri. Records of some other species in previous studies [9, 17], e.g., Dendrelaphis subocularis, Lycodon septentrionalis, and Hebius modestum need to be verified by examination of voucher specimens and thus we excluded these species from the list of snakes from Xuan Lien Nature Reserve.

Among 38 recorded species, four species are listed in the IUCN Red List (2016): Python molurus, Bungarus slowinskii, Naja atra, and Ophiophagus hannah [6]; eight species are listed in the Vietnam Red Data Book (2007): Python molurus, Coelognathus radiatus, Oreocryptophis porphyraceus, Ptyas korros, $P$. mucosa, Bungarus fasciatus, Naja atra, and Ophiophagus hannah [22]; and six species are listed in the Governmental Decree No. 32/2006/ND-CP 2006: Coelognathus radiatus, Ptyas mucosa, Bungarus fasciatus, $B$. multicinctus, Naja atra, and Ophiophagus hannah [22] (Table 1). In addition, two other species, Bungarus slowinskii and Parahelicops annamensis, are currently known only from the Indochina region. 
Table 1. List of snake species recorded in the Xuan Lien Nature Reserve, Thanh Hoa Province, Vietnam

\begin{tabular}{|c|c|c|c|c|}
\hline Species name & $\begin{array}{l}\text { Previous } \\
\text { record }\end{array}$ & $\begin{array}{l}\text { IUCN } \\
(2016) \\
\end{array}$ & $\begin{array}{l}\text { RBVN } \\
(2007)\end{array}$ & $\begin{array}{c}\text { Decree } \\
32(2006)\end{array}$ \\
\hline \multicolumn{5}{|l|}{ Pythonidae } \\
\hline Python molurus (Linnaeus, 1758) & 1,2 & VU & $\mathrm{CR}$ & \\
\hline \multicolumn{5}{|l|}{ Xenopeltidae } \\
\hline Xenopeltis unicolor Reinwardt, 1827 & 1 & & & \\
\hline \multicolumn{5}{|l|}{ Colubridae } \\
\hline Ahaetulla prasina (Boie, 1827) & $1,2,3$ & & & \\
\hline Boiga guangxiensis Wen, 1998 & 1 & & & \\
\hline Boiga multomaculata (Boie, 1827) & $1,2,3$ & & & \\
\hline Calamaria septentrionalis (Boulenger, 1890) & 2,3 & & & \\
\hline Coelognathus radiatus (Boie 1827) & 1,2 & & EN & IIB \\
\hline Cyclophiops multicinctus (Roux, 1907) & 2,3 & & & \\
\hline Dendrelaphis pictus (Gmelin, 1789) & 1 & & & \\
\hline Dryocalamus davisonii Boulenger, 1893 & 2 & & & \\
\hline Gonyosoma boulengeri (Mocquard, 1897) & 1 & & & \\
\hline Lycodon futsingensis (Pope, 1928)* & 3 & & & \\
\hline Lycodon meridionalis (Bourret, 1935)* & 3 & & & \\
\hline Oligodon chinensis (Günther, 1888) & 1 & & & \\
\hline Oligodon taeniatus (Günther, 1861) & 1 & & & \\
\hline Oreocryptophis porphyraceus (Cantor, 1839)* & 3 & & VU & \\
\hline Ptyas korros (Schlegel, 1837) & 1,2 & & EN & \\
\hline Ptyas mucosa Linnaeus, 1758 & 1,2 & & EN & IIB \\
\hline \multicolumn{5}{|l|}{ Homalopsidae } \\
\hline Hypsiscopus plumbea (Boie, 1827) & 1,2 & & & \\
\hline Myrrophis chinensis (Gray, 1842) & 1 & & & \\
\hline \multicolumn{5}{|l|}{ Lamprophiidae } \\
\hline Psammodynastes pulverulentus (Boie, 1827) & 2,3 & & & \\
\hline \multicolumn{5}{|l|}{ Natricidae } \\
\hline Amphiesma stolatum (Linnaeus, 1758) & 1 & & & \\
\hline Hebius boulengeri (Gressitt, 1937)* & 3 & & & \\
\hline Parahelicops annamensis Bourret, 1934* & 3 & & & \\
\hline Rhabdophis subminiatus (Schlegel, 1837) & $1,2,3$ & & & \\
\hline Sinonatrix aequifasciata (Barbour, 1908) & 1 & & & \\
\hline Sinonatrix percarinata Boulenger, 1899 & 2,3 & & & \\
\hline Xenochrophis flavipunctatus (Hallowell, 1860) & 1 & & & \\
\hline \multicolumn{5}{|l|}{ Pareatidae } \\
\hline Pareas hamptoni (Boulenger, 1905) & $1,2,3$ & & & \\
\hline \multicolumn{5}{|l|}{ Elapidae } \\
\hline Bungarus fasciatus (Schneider, 1801) & 1,2 & & EN & IIB \\
\hline Bungarus multicinctus Blyth, 1861 & 1,2 & & & IIB \\
\hline $\begin{array}{l}\text { Bungarus slowinskii Kuch, Kizirian, Nguyen, } \\
\text { Lawson, Donnelly \& Mebs, 2005* }\end{array}$ & 3 & VU & & \\
\hline Naja atra Cantor, 1842 & 1 & VU & EN & IIB \\
\hline Ophiophagus hannah Cantor, 1836 & 1,2 & VU & $\mathrm{CR}$ & IB \\
\hline Sinomicrurus macclellandi (Reinhardt, 1844) & 1 & & & \\
\hline Viperidae & & & & \\
\hline
\end{tabular}




\begin{tabular}{|c|c|}
\hline Protobothrops muscrosquamatus (Cantor, 1839) & 2,3 \\
\hline Trimeresurus albolabris Gray, 1842 & $1,2,3$ \\
\hline Trimeresurus stejnegeri Schmidt, 1925 & 2,3 \\
\hline
\end{tabular}

\section{CONCLUSION}

A total of 38 species of snakes were recorded from Xuan Lien Nature Reserve, Thanh Hoa province. In terms of species richness, the most diverse family is Colubridae with 16 recorded species, followed by Natricidae (7 species) and Elapidae (6 species). The snake fauna of Xuan Lien Nature Reserve contains a high level of species of conservation concern with six species listed in the Governmental Decree No. 32/2006/ND-CP (2006), eight species listed in the Vietnam Red Data Book (2007), and four species listed in the IUCN Red List (2016).

Acknowledgments: We are grateful to Hai Dinh Nguyen, Director of Xuan Lien Nature Reserve (Thanh Hoa) for support of our field work and issuing relevant permits. Many thanks to Hoang Van Chung, Nguyen Thien Tao, Chu Thi Thao, Dang Huy Phuong (Hanoi) and rangers of the Xuan Lien NR for their assistance in the field. This research was partially funded by the Vietnam Academy of Science and Technology (Grant No. VAST 04.08/12-13).

\section{REFERENCES}

1. David P., Agarwal I., Athreya R., Mathew R., Vogel G., Mistry V. K., 2015a. Revalidation of Natrix clerki Wall, 1925, an overlooked species in the genus Amphiesma Duméril, Bibron \& Duméril, 1854 (Squamata: Natricidae). Zootaxa, 3919(2): 375-395.

2. David P., Pauwels O. S. G., Nguyen T. Q., Vogel G., 2015b. On the taxonomic status of the Thai endemic freshwater snake Parahelicops boonsongi, with the erection of a new genus (Squamata: Natricidae). Zootaxa, 3948(2): 203-217.
3. David P., Vogel G., Johan J. V., 2013. On some taxonomically confused species of the genus Amphiesma Duméril, Bibron \& Duméril, 1854 related to Amphiesma khasiense (Boulenger, 1890) (Squamata, Natricidae). Zootaxa, 3694(4): 301-335.

4. Gressit J. L., 1937. A new snake from southeastern China. Proc. Biol. Soc. Washington, 50: 125-128

5. Hecht V. L., Pham C. T., Nguyen T. T., Nguyen T. Q., Bonkowski M., Ziegler T., 2013. First report on the herpetofauna of Tay Yen Tu Nature Reserve, northeastern Vietnam. Biodiver. Jour., 4(4): 507-552.

6. IUCN, 2016. The IUCN Red List of Threatened Species. Version 2016.4. http://www.iucnredlist.org. Accessed on 20 April 2016.

7. Kharin V. E., Orlov N. L., Anajeva N. B., 2011. New records and redescription of rare and little-known Elapid snake Bungarus slowinski. Russ. Jour. Herpetol., 18(4): 284294.

8. Kuch U., Kizirian D., Nguyen T. Q., Lawson R., Donelly M. A., Mebs D., 2005. A new species of krait (Squamata: Elapidae) from the Red river system of North Vietnam. Copeia, 2005(4): 818-833.

9. Le N. N., Pham A. V., 2009. The results of survey on amphibians and reptiles in Xuan Lien Nature Reserve, Thanh Hoa province. Vietnam Nat. Univ. Jour. Sci., 54: 90-100 (in Vietnamese).

10. Le T. T., Le C. V., Bui T. D., Tran M. H., Tran N. Q., Nguyen, S. V., Monastyrskii A. L., Eames J. C., 1999. A feasibility study for the establishment of Xuan Lien Nature 
Reserve, Thanh Hoa Province, Vietnam. Birdlife International: Conservation Report, $56 \mathrm{pp}$.

11. Luu V. Q., Nguyen T. Q., Calame T., Hoang T. T., Southichack S., Bonkowski M., Ziegler T., 2013a. New country records of reptiles from Laos. Biodiver. Data Jour., 1: e 10105.

12. Luu V. Q., Nguyen T. Q., Pham C. T., Dang K. N., Vu T. N., Miskovic S., Bonkowski M., Ziegler T., 2013b. No end in sight? Further new records of amphibians and reptiles from Phong Nha - Ke Bang National Park, Quang Binh province, Vietnam. Biodiver. Jour., 4: 285-300.

13. Nguyen S. V., Ho C. T., Nguyen T. Q., 2009. Herpetofauna of Vietnam. Edition Chimaira, Frankfurt am Main, 768 pp.

14. Nguyen T. Q., An H. T., Nguyen T. T., Luu V. Q., Tran T. T., Ziegler T., 2014. New records of reptiles from northern Vietnam. Abhandl. Natur. Ver. Bremen, 47: 247-254.

15. Nguyen T. T, Nguyen L. T., Pham T. V., Nguyen M. D., Truong V. V., Nguyen S. N., 2015. Preliminary results on species composition of the reptiles in $\mathrm{Pu}$ Luong Nature Reserve, Thanh Hoa Province. Proceeding of the sixth Nationnal Scientific Conference on Ecology and Biological Resources, Agricultural Publishing House, Hanoi, pp. 878-882 (in Vietnamese).

16. Orlov N. L., Ryabov S. A., 2004. Revalidization and change of taxonomic status of Dinodon rufozonatum meridionale Bourret, 1935 (Serpentes: Colubridae: Colubrinae). Russ. Jour. Herpetol., 11(3): 181-197.

17. Pham C. T., Hoang C. V., Nguyen T. Q., Chu T. T., Nguyen T. T., 2012. Species composition of the herpetofauna of Xuan Lien Nature Reserve, Thanh Hoa province. Proceedings of the second National Workshop on Herpetology of Vietnam, Vinh University Publishing House, pp. 112119 (in Vietnamese).

18. Pham C. T., Nguyen T. Q., Hoang C. V., Ziegler T., 2016. New records and an updated list of amphibians from Xuan Lien nature reserve, Thanh Hoa province, Vietnam. Herpetol. Notes, 9: 31-41.

19. Schulz K. D., 1996. Monograph of the Colubrid snakes of the genus Elaphe Fitzinger. Koeltz Scientific Books, Havlickuv Brod, 439 pp.

20. Smith M. A., 1943. The fauna of British India, Ceylon and Burma, including the whole of the Indo-Chinese Subregion. Reptilia and Amphibia. Vol. III. Serpentes Taylor and Francis (London), 440 pp.

21. Stuart B. L., 2006. A second specimen of Parahelicops annamensis Bourret, 1934 (Serpentes: Colubridae: Natricinae). Hamadryad, 30: 167-171.

22. The Government of Vietnam, 2006. The Governmental Decree No. 32/2006/NĐ-CP, dated on 30th March 2006, on management of endangered, precious, and rare species of wild plants and animals, $13 \mathrm{pp}$.

23. Tran K., Ho C. T., Nguyen S. V., Pham T., 2007. Reptiles and Amphibians. In: Dang T. N., Tran K., Dang H. H., Nguyen C., Nguyen T. N., Nguyen Y. H., Dang D. T., (Eds.). Vietnam Red Data Book, Part 1. Animals,. Science and Technology Publishing House, Hanoi, pp. 219-276 + 8pls (in Vietnamese).

24. Uetz P., Hošek J., 2016. The Reptile Database. Available from. http://www.reptile database.org (accessed on 5 June 2016)

25. Vogel G., David P., Pauwels O. S. G., Sumontha M., Norval G., Hendrix R., Vu N. T., Ziegler T., 2009. A revision of Lycodon ruhstrati (Fischer 1886) auctorum (Squamata: Colubridae), with the description of a new species from Thailand and a new subspecies from the Asian mainland. Tropic. Zool., 22: 131-182.

26. Ziegler T., Tran D. T. A, Nguyen T. Q., Perl R. G. B., Wirk L., Kulisch M., Lehmann T., Rauhaus A., Nguyen T. T., Le Q. K., Vu T. N., 2014. New amphibian and reptile records from Ha Giang province, Northern Vietnam. Herpetol. Notes, 7: 185-201. 


\title{
GHI NHẬ̂ PHÂN BỐ MỚI VÀ DANH SÁCH CẬP NHẬT CỦA CÁC LOÀI RẤN (Squamata: Serpentes) Ở KHU BẢO TỒN THIÊN NHIÊN XUÂN LIÊN, TỈNH THANH HÓA
}

\author{
Nguyễn Văn Tân, Phạm Thế Cường, Nguyễn Quảng Trường
}

Viện Sinh thái và Tài nguyên sinh vật, Viện Hàn lâm KH \& CN Việt Nam

\section{TÓM TÁT}

Trong bài báo này, chúng tôi ghi nhận bổ sung phân bố của 6 loài rắn ở tỉnh Thanh Hóa dựa trên bộ mẫu vật thu được từ khu Bảo tồn Thiên nhiên Xuân Liên, bao gồm 3 loài thuộc họ Colubridae: Lycodon futsingensis, L. meridionalis và Oreocryptophis porphyraceus; 2 loài thuộc họ Natricidae: Hebius boulengeri và Parahelicops annamensis, và 1 loài thuộc họ Elapidae: Bungarus slowinskii. Ngoài ra, chúng tôi cập nhật danh sách 38 loài rắn ghi nhận ở Khu Bảo tồn thiên nhiên Xuân Liên, trong đó có 6 loài có tên trong Nghị Định 32/2006/NĐ-CP của Chính phủ, 8 loài bị đe dọa cấp quốc gia có tên trong Sách Đỏ Việt Nam (2007) và 4 loài bị đe dọa cấp toàn cầu có tên trong Danh lục Đỏ IUCN (2016).

Từ khóa: Rắn, danh sách loài, phân bố, Khu Bảo tồn thiên nhiên Xuân Liên.

Received: 26 June 2016, accepted 20 September 2016 